\title{
Оценка воздействия
}

многосторонних

механизмов помощи

\section{на социально-экономическое развитие Вьетнама}

Ю.К. Зайцев

\begin{abstract}
В статье проводится анализ мер многосторонних доноров, направленных на содействие сочиально-экономическому развитию Вьетнама. Автор рассматривает программы многосторонних доноров по основным секторам СМР, а также проводит оценку воздействия этих программ на показатели социально-экономического развития. В заключение автор на основе данных эконометрической модели отмечает тенденцию смещения акцента действий многосторонних доноров страдиционных программ развития на программы по интеграции странпартнеров в мирохозяйственные отношения.
\end{abstract}

$\mathrm{B}$ настоящее время Вьетнам входит в пятерку крупнейших получателей официальной помощи развитию (ОПР) в мире. Общий объем обещанной и предоставленной донорами помощи Вьетнаму значительно возрос за последнее десятилетие, составив 2,4 млн долл. США и 1,65 млн долл. США в 2000 и 5,01 млн долл. США и 1,94 млн долл. США в 2008 г. ${ }^{1}$ Тем не менее Вьетнам не является страной, полностью зависимой от помощи, поскольку ОПР составляет незначительную долю от ресурсов, направляемых на содействие экономическому развитию страны. Так, доля ОПР от валового национального дохода (ВНД) сократилась с $5,9 \%$ в 2000 г. до $2,2 \%$ в 2008 г., а доля ОПР в национальном бюджете сократилась с $23,9 \%$ в 2000 г. до 7,1\% в 2008 г. ${ }^{2}$ Общий объем помощи уступает объемам прямых иностранных инвестиций (ПИИ), доходов от туризма и денежных переводов. Тем не менее ОПР все еще остается существенным источником финансирования программ развития во Вьетнаме и составляет порядка 12-13\% ресурсов, которые потенциально могут быть использованы в качестве государственных инвестиций ${ }^{3}$.
Успехи Вьетнама по реализации программ в сфере развития региона, а также высокие показатели реализации повестки дня по повышению эффективности помощи способствовали увеличению числа доноров в стране с 40 в 2000 г. до 51 в 2009 г. (28 двусторонних и 23 многосторонних доноров). Помимо традиционных доноров, стран-членов Комитета содействия развитию Организации экономического сотрудничества и развития (КСР ОЭСР), в регионе активно работают доноры, не являющиеся членами комитета, объем обязательств по финансированию развития которых превысил 560 млн долл. США (2000 г.), что составило порядка $2 \%$ от общего объема ОПР, предоставленной региону. При этом в число суверенных доноров вошли страны Восточной и Юго-Восточной Азии, Ближнего Востока. Крупнейшим из данной категории доноров стал Китай, объем финансовых обязательств которого составил 560 млн долл. США. Крупнейшими многосторонними донорами стали институты Всемирного банка, Азиатский банк развития. Вьетнам является страной, концентрирующей большое число инвестиционных проектов, инициированных небольшим числом доноров.

Зайцев Юрий Константинович - н.с. Центра международных проектов Института статистических исследований и экономики знаний Национального исследовательского института «Высшая школа экономики». E-mail: yuriy.zaitsev@gmail.com 


\section{- Иностранная помощь и развитие}

С методологической точки зрения деятельность многосторонних доноров по развитию секторов, имеющих ключевое значение для социально-экономического развития Вьетнама, можно подразделить на две категории: меры, направленные на непосредственное социально-экономическое развитие страны (региона), и меры, направленные на интеграцию страны-партнера в процессы мировой экономики. В число основных мер, относящихся к первой категории, входят программы в сфере здравоохранения, образования, инфраструктуры. Ко второй категории можно отнести программы по развитию торговли, привлечению инвестиций и развитию инвестиционного климата, а также программы, связанные с укреплением региональных производственных цепочек, в которых участвует Вьетнам.

Программы многосторонних доноров во Вьетнаме. Рассмотренные в статье программы многосторонних доноров, направленные на развитие секторов здравоохранения, образования, инфраструктуры, имеют первостепенное значение для национальной экономики Вьетнама и повышения показателей экономического роста. Действия доноров по интеграции Вьетнама в процессы мировой экономики будут рассматриваться в рамках программ по содействию развитию торговли и инвестиций с помощью улучшения инвестиционного климата.

В период с 2000 по 2009 г. основная доля помощи (63\%) приходилась на развитие экономического сектора и составила 19 млрд долл. США 4 . Следующими по уровню предоставленной помощи стали сектора транспортной инфраструктуры (27\% ОПР), энергетической инфраструктуры (17\%), сельскохозяйственный сектор (7\%). Программы, связанные с развитием социального сектора, а также с развитием энергетической инфраструктуры получили финансирование в размере 4,7 млрд долл. США или $16 \%$ от общего объема ОПР. Финансирование программ, направленных на обеспечение перехода к рыночной экономике (таких, как общая поддержка государственного бюджета, административная реформа, создание благоприятного бизнес-климата), составило 4,4 млрд долл. США (или 14\% от общего объема ОПР), В это же время финансирование других секторов (в том числе сектора обеспечения безопасности) составило 2,2 млрд долл. США (7\%).

Представим анализ программ многосторонних доноров для каждого из рассмотренных в исследовании секторов.

Образование. Согласно данным Министерства образования Вьетнама, доступ к высшему образованию в стране имеет только $2 \%$ населения 5 . Этот показатель является низким как для ЮгоВосточной Азии, так и в международном измерении в целом. Цели развития сектора образования Вьетнама закреплены в рамках «Плана социально-экономического развития Вьетнама» ${ }^{6}$ и «Pезолюции по комплексному и фундаментальному реформированию системы высшего образования Вьетнама в период 2006 - 2020 гг.» ${ }^{7}$.

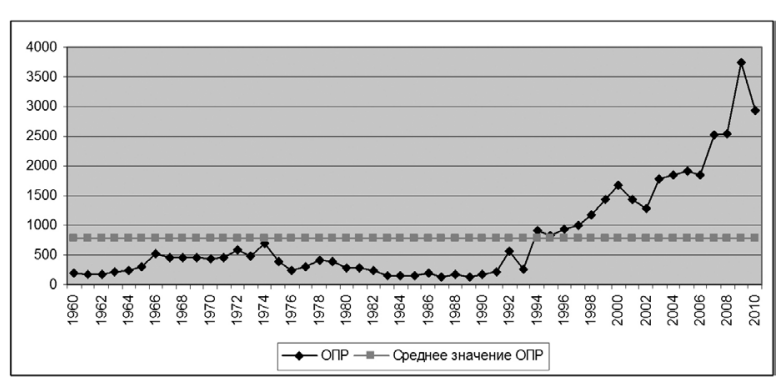

Рис.1. Объемь ОПР, предоставленной

Вветнаму в период 1960-2010 г2. (млн долл. CIIA).

В число основных целей развития сектора высшего образования вошло увеличение:

- численности профессорско-преподавательского состава (ППС), имеющих степень магистра и $\mathrm{PhD}$ к 2020 г. до 60\% и 35\% соответственно;

- числа частных университетов, в том числе, с иностранным финансированием;

- увеличение числа студентов к 2020 г. до 450 человек на 10 тыс. населения Вьетнама.

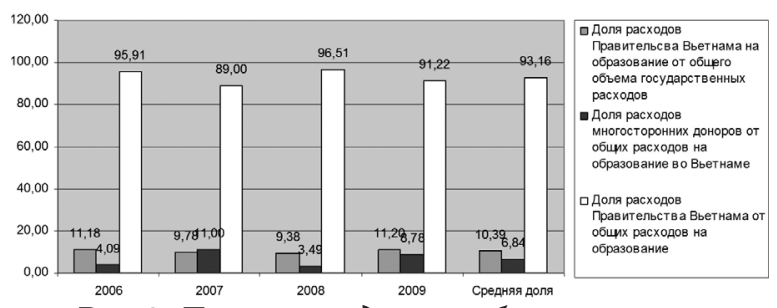

Рис.2. Доли расходов на образование правительства Вветнама и многосторонних доноров.

В секторе содействия развитию образования рассматривались программы по развитию:

- непрерывного образования и развитию ключевых навыков молодежи и взрослого населения (lifelong learning, basic skills for youth and adults);

- основного образования (basic education), которое включало начальное образование (primary education), начальное образование для детей (early childhood education) и среднее образование (secondary education).

Табтииа 1

Расходы на образование (млрд долл. США)

\begin{tabular}{|l|l|l|l|l|l|}
\hline & 2006 & 2007 & 2008 & 2009 & Bсего \\
\hline $\begin{array}{l}\text { Расходы на образование } \\
\text { Правительства Вьетнама }\end{array}$ & 1,64 & 1,86 & 2,21 & 2,39 & 8,1 \\
\hline $\begin{array}{l}\text { Расходы на образование } \\
\text { многосторонних доноров }\end{array}$ & 0,07 & 0,23 & 0,08 & 0,23 & 0,61 \\
\hline $\begin{array}{l}\text { Общий объем } \\
\text { государственных } \\
\text { расходов }\end{array}$ & 14,67 & 19,01 & 23,55 & 21,34 & 78,57 \\
\hline $\begin{array}{l}\text { Бензиновая } \\
\text { энергетическая } \\
\text { установка }\end{array}$ & 0,268 & 0,371 & 0,004 & 0,005 & 0,001 \\
\hline
\end{tabular}

Источник: Статистика Правительства Вьетнама, собст венные расчеты автора.

Расходы многосторонних доноров в секторе образования были главным образом сфокусированы на развитии основного (базового среднего) образования, в то время как сектору высшего образования, который нуждается в большей степени во внешнем финансировании, было уделено меньшее внимание (34,85\% от общего объема 
помощи, направляемой в сектор образования). Наибольший вклад в развитие сектора среднего образования внес Азиатский банк развития. Совместно с Правительством Вьетнама банком был реализован широкий круг проектов, результатами которых стало обеспечение доступа к программам начального среднего образования (lower secondary education) для 90,4\% населения Вьетнама и к программам полного среднего образования (upper secondary education) для 55,3\% населения. Были также улучшены показатели, характеризующие соотношение числа учителей и учеников, количества поступивших участников и выпускников. Тем не менее приоритетными направлениями развития системы среднего образования все еще остаются повышение качества высшего образования в соответствии с международными стандартами, расширение доступа к возможностям получения среднего образования9 .

Необходимо отметить, что дальнейшее развитие сектора образования во Вьетнаме должно осуществляться по модели, в рамках которой при сохранении внешнего финансирования со стороны многосторонних доноров и частного сектора основная ответственность за развитие образования и формирование национального образовательного потенциала будет лежать на правительстве Вьетнама.

Здравоохранение. Уровень финансирования сектора здравоохранения во Вьетнаме превышает уровень финансирования многих стран Юго-Восточной Азии (6\% от ВВП). За период с 2006 по

Таблииа 2

Финансирование многосторонними донорами программ сектора образования во Вьетнаме за период 2006-2009 гг.

\begin{tabular}{|c|c|c|c|c|c|c|c|c|c|c|c|c|c|}
\hline & \multicolumn{3}{|c|}{2006} & \multicolumn{3}{|c|}{2007} & \multicolumn{3}{|c|}{2008} & \multicolumn{3}{|c|}{2009} & \multirow[b]{2}{*}{ Bcero } \\
\hline & $\begin{array}{l}\text { Основ- } \\
\text { ное } \\
\text { образо- } \\
\text { вание }\end{array}$ & $\begin{array}{l}\text { Bыс- } \\
\text { шеe } \\
\text { образо- } \\
\text { вание }\end{array}$ & $\begin{array}{l}\text { Обучение на } \\
\text { протяжении } \\
\text { всей жизни }\end{array}$ & $\begin{array}{l}\text { Ocнов- } \\
\text { ное } \\
\text { образо- } \\
\text { вание }\end{array}$ & $\begin{array}{l}\text { Высшее } \\
\text { образо- } \\
\text { вание }\end{array}$ & $\begin{array}{l}\text { Обучение на } \\
\text { протяжении } \\
\text { всей жизни }\end{array}$ & $\begin{array}{l}\text { Ocнов- } \\
\text { ное } \\
\text { образо- } \\
\text { вание }\end{array}$ & $\begin{array}{l}\text { Высшее } \\
\text { образо- } \\
\text { вание }\end{array}$ & $\begin{array}{l}\text { Обучение на } \\
\text { протяжении } \\
\text { всей жизни }\end{array}$ & $\begin{array}{l}\text { Ocнов- } \\
\text { ное } \\
\text { образо- } \\
\text { вание }\end{array}$ & $\begin{array}{l}\text { Высшее } \\
\text { образо- } \\
\text { вание }\end{array}$ & $\begin{array}{l}\text { 0бучение на } \\
\text { протяжении } \\
\text { всей жизни }\end{array}$ & \\
\hline EC & 0,99 & 0,15 & 0,73 & 14,78 & 0,01 & 0,14 & 2,1 & 0,13 & 0 & 2,79 & 0,24 & 0 & 22,07 \\
\hline MAP & 13,84 & 19,93 & 0 & 85,45 & 15,37 & 0 & 31,39 & 8,44 & 0 & 48,61 & 63,51 & 0 & 286,54 \\
\hline ЮНИСЕФ & 0,15 & 0 & 0 & 0,24 & 0 & 0 & 0,17 & 0 & 0 & 0,06 & 0 & 0,06 & 0,68 \\
\hline $\begin{array}{l}\text { Bcero no } \\
\text { сферам }\end{array}$ & 14,98 & 20,07 & 0,73 & 100,47 & 15,38 & 0,14 & 33,67 & 8,57 & 0 & 51,46 & 63,75 & 0,06 & 309,29 \\
\hline Bcero & \multicolumn{3}{|l|}{71,57} & \multicolumn{3}{|l|}{231,98} & \multicolumn{3}{|l|}{84,47} & \multicolumn{3}{|l|}{230,54} & 618,58 \\
\hline
\end{tabular}

Источник: КСР ОЭСР, собственные расчеты автора

2010 г. средняя доля государственных расходов составила 7,03\% от ВВП страны ${ }^{10}$. Этот показатель меньше среднего показателя по странам Европы $(13 \%)$ и даже по странам Африки $(10 \%)^{11}$. При этом государством покрывается порядка одной четверти всех расходов на здравоохранение, что составляет порядка 6\% от общих государственных расходов ${ }^{12}$.

Доля расходов на здравоохранение во Вьетнаме многосторонних доноров за рассмотренный период не превышала 4\% от общих государственных расходов в этом секторе ${ }^{13}$. Они шли прежде всего на реализацию базовых программ (basic healthcare), действия по борьбе с туберкулезом, малярией и СПИДом (fighting tuberculosis, malaria and HIV/AIDS), а также на осуществление контроля над инфекционными заболеваниями (infectious diseases control).

В частности, по линии реализации базовых программ по здравоохранению рассматривалась поддержка реализации национальной политики в сфере здравоохранения (health policy), управление программами, предоставление медицинских услуг. Во все рассмотренные периоды расходы по этой категории составили наибольшую долю финансирования многосторонних организаций (98,83 млн долл. США, или 74\%).

Другими двумя крупными направлениями расходов многосторонних организаций в сфере здравоохранения стали контроль над инфекционными заболеваниями и борьба с малярией, туберкулезом и СПИДом. Необходимость внешнего финансирования данных сфер является особенно ощутимой в силу недостаточного уровня ресурсов, предоставляемого национальным правительством. Так, с 2000 г. уровень государственного финансирования программ по борьбе с ВИЧ/СПИДом в среднем не превысил 63 тыс. долл. США ежегодно ${ }^{15}$.

Таблииа 3

Расходы на здравоохранение (\%)

\begin{tabular}{|l|l|l|l|l|l|}
\hline & 2006 & $\mathbf{2 0 0 7}$ & $\mathbf{2 0 0 8}$ & $\mathbf{2 0 0 9}$ & $\begin{array}{l}\text { (реднее } \\
\text { 3наче- } \\
\text { ние }\end{array}$ \\
\hline $\begin{array}{l}\text { Доля общих расходов на } \\
\text { здравоохранение от ВВП }\end{array}$ & 6,6 & 7,1 & 7,2 & 7,2 & 7,03 \\
\hline $\begin{array}{l}\text { Доля государственных } \\
\text { расходов на } \\
\text { здравоохранение } \\
\text { от общего объема } \\
\text { государственных } \\
\text { расходов }\end{array}$ & 6,4 & 8,7 & 9,3 & 8,9 & 8,33 \\
\hline $\begin{array}{l}\text { Доля государственных } \\
\text { расходов на } \\
\text { здравоохранение от } \\
\text { общих расходов на } \\
\text { здравоохранение во } \\
\text { Вьетнаме }\end{array}$ & 32,3 & 39,3 & 38,5 & 38,7 & 37,2 \\
\hline $\begin{array}{l}\text { Доля расходов } \\
\text { многосторонних } \\
\text { доноров от общих } \\
\text { государственных } \\
\text { расходов в секторе } \\
\text { здравоохранения }\end{array}$ & 4,4 & 3,3 & 3,9 & 4,5 & 4,0 \\
\hline
\end{tabular}

Источник: статистика Правительства Вьетнама, собственные расчеты автора ${ }^{14}$.

Основным приоритетом для многосторонних доноров, участвующих в программах содействия развитию сектора здравоохранения, стала борьба с болезнями, передающимися через коммуникацию ${ }^{16}$. Наибольшая доля помощи была предоставлена для борьбы с ВИЧ/СПИДом. При этом объем внешней многосторонней помощи, направляемой 
-

Иностранная помощь и развитие

на борьбу с ВИЧ/СПИДом, составлял порядка 80\% от общих расходов Вьетнама, направляемых на борьбу с ВИЧ/СПИДом.

Таким образом, внешнее финансирование, предоставляемое донорами, играет особую роль в реализации программ по борьбе с ВИЧ/СПИДом. Необходимо отметить, что доля расходов, рассмотренных многосторонними институтами на финансирование программ по борьбе с ВИЧ/СПИДом, туберкулезом и малярией, составила порядка $24 \%$ от всех расходов доноров в данном секторе. В частности, Всемирным банком за период с 2006 по 2009 г. было выделено более 70 млн долл. США.

Среди всех возможностей по преодолению недостатка средств для увеличения финансирования здравоохранения наиболее реалистичным вариантом представляется увеличение доли государственного бюджета, расходуемой на реализацию программ в этой сфере. Вьетнамское правительство также могло бы укрепить и расширить систему государственного медицинского страхования, в котором в настоящее время действуют лишь частные структуры. Власти Вьетнама должны играть центральную роль в мобилизации ресурсов для покрытия прямых и части непрямых затрат в сфере здравоохранения. Только тогда сообщество доноров в лице многосторонних организаций сможет осуществлять поддерживающую функцию в реализации политики, связанной со снижением бедности через поддержку сферы здравоохранения Вьетнама ${ }^{17}$.

Инфраструктура. Порядка половины всех обязательств по предоставлению ОПР Вьетнаму за прошедшее десятилетие были связаны с развитием инфраструктуры. При этом большую долю финансирования получили проекты, направленные на развитие транспорта, в том числе строительство мостов и восстановление транспортных магистралей. Наибольший вклад в реализацию проектов внесли Япония, Всемирный банк, а также Азиатский банк развития. Действия Японии, которая является крупнейшим донором в сфере развития инфраструктуры Вьетнама, были направлены на обновление городской и сельской транспортной инфраструктуры, строительство термальных электростанций, которые вырабатывают порядка 20\% всей энергетики во Вьетнаме.

Всемирный банк, будучи вторым по величине донором в сфере развития инфраструктуры, поддерживал проекты по строительству автодорог и развитию электросети в сельской местности. Азиатский банк развития за рассмотренный период активно реализовывал программы, направленные на обеспечение питьевой водой, предоставлял займы на развитие сети автодорог в городской и сельской местности, а также способствовал развитию сбалансированной системы энергообеспечения при использовании гидроэнергии, газа и угля.

Многосторонние доноры достаточно активно вкладывали средства в развитие сектора инфраструктуры в сельском хозяйстве. Здесь доминировали программы по интенсификации сельскохозяйственного производства, развитию животноводства, производству продовольственных культур, обеспечению водных ресурсов для сельского хозяйства, управлению сельским хозяйством и выработке сельскохозяйственной политики. Среди программ городского развития были проанализированы программы по: управлению городским сектором, развитию ЖКХ, развитию сети передачи и распределения электричества, утилизации и управлению отходами. В части содействия развития транспорта рассматривались программы по укреплению политики в сфере развития наземного, водного транспорта.

Среди обозначенных секторов сферы инфраструктуры наиболее приоритетным направлением для Вьетнама является содействие развитию инфраструктуры в секторе сельского хозяйства. На протяжении последних 25 лет сельскохозяйственный сектор вносил существенный вклад в снижение уровня бедности во Вьетнаме ${ }^{18}$. Так, уровень бедности в сельскохозяйственных районах упал с 66\% в 1993 г. до 36\% в 2006 г. В настоящее время сектор сельского хозяйства формирует порядка пятой части ВВП страны, обеспечивает одну треть экспорта. Оно же предоставляет две трети рабочих мест в стране.

Таблица 4

Финансирование многосторонними донорами программ сектора здравоохранения во Вьетнаме за период 2006 - 2009 гг. (млн долл. СШША)

\begin{tabular}{|c|c|c|c|c|c|c|c|c|c|c|c|c|c|}
\hline & \multicolumn{3}{|c|}{2006} & \multicolumn{3}{|c|}{2007} & \multicolumn{3}{|c|}{2008} & \multicolumn{3}{|c|}{2009} & \multirow[b]{2}{*}{$\begin{array}{c}\text { Bcero } \\
\text { по } \\
\text { инсти- } \\
\text { тутам }\end{array}$} \\
\hline & $\begin{array}{l}\text { Oснов- } \\
\text { ные } \\
\text { услуги } \\
\text { здраво- } \\
\text { охране- } \\
\text { ния }\end{array}$ & $\begin{array}{l}\text { Маля- } \\
\text { рия, } \\
\text { тубер- } \\
\text { кулез, } \\
\text { спид }\end{array}$ & $\begin{array}{l}\text { Контроль } \\
\text { над инфек- } \\
\text { ционными } \\
\text { заболева- } \\
\text { ниями }\end{array}$ & $\begin{array}{l}\text { Основ- } \\
\text { ные } \\
\text { услуги } \\
\text { здраво- } \\
\text { оране- } \\
\text { ния }\end{array}$ & $\begin{array}{l}\text { Маля- } \\
\text { рия, } \\
\text { тубер- } \\
\text { кулез, } \\
\text { сіидд }\end{array}$ & $\begin{array}{l}\text { Контроль } \\
\text { над } \\
\text { инфекци- } \\
\text { онными } \\
\text { заболева- } \\
\text { ниями }\end{array}$ & $\begin{array}{l}\text { Oснов- } \\
\text { ные } \\
\text { услуги } \\
\text { здраво- } \\
\text { охране- } \\
\text { ния }\end{array}$ & $\begin{array}{l}\text { Маля- } \\
\text { рия, } \\
\text { тубер- } \\
\text { кулез, } \\
\text { спид }\end{array}$ & $\begin{array}{l}\text { Контроль } \\
\text { над инфек- } \\
\text { ционнымим } \\
\text { заболева- } \\
\text { ниями }\end{array}$ & $\begin{array}{l}\text { Основ- } \\
\text { ные } \\
\text { услуги } \\
\text { здраво- } \\
\text { орране- } \\
\text { ния }\end{array}$ & $\begin{array}{l}\text { Маля- } \\
\text { рия, } \\
\text { тубер- } \\
\text { кулез, } \\
\text { спидд }\end{array}$ & $\begin{array}{l}\text { Контроль } \\
\text { над } \\
\text { инфекци- } \\
\text { онными } \\
\text { заболева- } \\
\text { ниями }\end{array}$ & \\
\hline $\begin{array}{l}\text { Институты } \\
\text { ЕС }\end{array}$ & 9,2 & & & 1,4 & & & 0,001 & & & 1,56 & & & 12,17 \\
\hline MAP & 10,2 & 3,7 & & 18,97 & 4,9 & & 30,08 & 6,49 & 0,15 & 27,45 & 12,43 & 2,79 & 117,29 \\
\hline $\begin{array}{l}\text { Институты } \\
\text { ООН: } \\
\text { ПРООН, } \\
\text { ЮНЭЙДС, } \\
\text { ЮНИСЭФ, } \\
\text { ЮНПФА }\end{array}$ & 0,01 & 0,7 & 0,08 & & 1,51 & 0,10 & & 0,55 & 0,03 & & 0,82 & & 3,89 \\
\hline $\begin{array}{l}\text { Bcero no } \\
\text { сферам }\end{array}$ & 19,4 & 4,5 & 0,08 & 20,37 & 6,49 & 0,10 & 30,08 & 7,05 & 0,17 & 29,01 & 13,25 & 2,79 & \\
\hline Bcero & \multicolumn{3}{|l|}{24,04} & \multicolumn{3}{|l|}{26,96} & \multicolumn{3}{|l|}{37,29} & \multicolumn{3}{|l|}{45,05} & 133,34 \\
\hline
\end{tabular}

Источник: данные КСР ОЭСР, собственные расчеты автора. 
В докризисный период доля финансирования доноров снижалась, но оставалась на достаточно высоком уровне. Одной из основных проблем в развитии сельскохозяйственной инфраструктуры во Вьетнаме является отсутствие возможности оценить окупаемость вкладываемых в этот сектор инвестиций. Бюджетная классификация и способ учета затрат не позволяют провести детальный анализ государственных затрат, а также провести оценку их эффективности. В случае же многосторонних доноров информация о предоставленных ресурсах является доступной. Но из-за отсутствия систематизированных данных о национальном финансировании сельскохозяйственной инфраструктуры анализ воздействия донорских программ на социально-экономическое развитие сельскохозяйственных регионов и их соотношения с национальными программами затруднителен.

Тем не менее можно констатировать несколько реальных фактов. На протяжении рассматриваемого периода государственные расходы на развитие инфраструктуры в сфере сельского хозяйства существенно превосходили расходы многосторонних доноров (средняя доля за рассмотренный период составила $80,42 \%$ от совокупных расходов). В свою очередь, средняя доля ресурсов, направляемая многосторонними организациями в этот сектор, составила в рассматриваемый период 9,37\%, что указывает на действенность государственных механизмов в сфере развития сельского хозяйства и его инфраструктуры ${ }^{19}$.

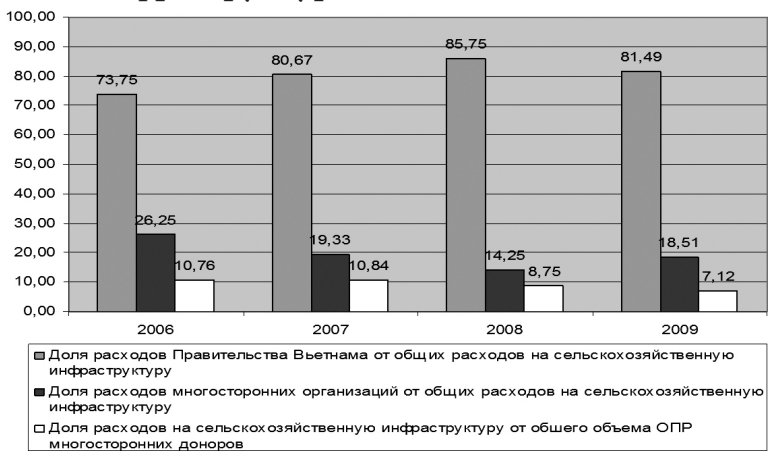

Рис.3. Доли расходов в иелях укрепления сельскохозяйственной инфраструктуры.

Содействие развитию транспортной инфраструктуры стало также одним из приоритетных направлений многосторонних доноров во Вьетнаме. Начатая в данном направлении еще в 1993 г. работа способствовала расширению транспортной сети с 13 тыс. км в 1997 г. до 48 тыс. км в 2008 г. Это привело к увеличению пассажиропотока до 1 млрд человек, а также расширило возможности для перевоза товаров. Более того, инвестиции в транспортную инфраструктуру, предоставленные многосторонними донорами, способствовали привлечению инвестиций из частного сектора, что в свою очередь привело к увеличению уровня занятости и снижению уровня бедности в регионе ${ }^{20}$.

Таким образом, воздействие многосторонних доноров в части, касающейся содействию социально-экономического развития Вьетнама, является необходимым и действенным преимущественно в секторе здравоохранения. В то же время большая часть действий по развитию инфраструктуры сосредоточена в секторе сельского хозяйства, за реализацию которых первостепенную ответственность несет национальное правительство Вьетнама. При этом в силу неразвитости системы национального учета весьма затруднительно оценить влияние национальных программ на развитие регионов и сопоставить их с программами доноров.

Инвестиции. Правительство Вьетнама в рамках рыночно ориентированной трансформации национальной экономики предприняло комплекс мер, направленных на привлечение иностранных инвестиций в страну. Еще в 1987г. Национальной ассамблеей Вьетнама был принят закон об иностранных инвестициях (Law on Foreign Investment) ${ }^{21}$. Дальнейшие меры по поддержке инвестиционного климата способствовали укреплению инвестиционных потоков. Финансовый кризис повлиял на снижение объема иностранных инвестиций в 1997 и в 2009 гг. Тем не менее объем ПИИ в среднем составляет порядка $30 \%$ от общего объема инвестиций в экономике Вьетнама 22 .

Несмотря на экономический и финансовый кризисы, в стране сохранился положительный экономический рост (5,3\%), что улучшило инвестиционный климат для многих международных компаний. В посткризисный период во Вьетнаме было реализовано более 10 тыс. инвестиционных проектов, средний объем которых составил порядка 4,5 млрд долл. США в год. Основными странами-инвесторами стали Малайзия, Китай, Япония, Сингапур, Республика Корея. Из стран-членов КСР ОЭСР в число основных доноров вошли Австралия, США, Канада, Франция, Великобритания, Нидерланды, объем ПИИ которых за период с 1998 по 2010 г. составил порядка 39\% от общего объема капитальных инвестиций. Инвестиции были предоставлены в двух основных формах: инвестиции международных компаний (57\%) и инвестиции, предоставленные в рамках совместных предприятий $(40 \%)^{23}$.

Ключевую роль в инвестиционном процессе играют транснациональные компании и предоставляемые ими ПИИ. Помимо функции интеграции Вьетнама в процессы мировой экономики, ТНК являются дополнительным источником для финансирования процессов развития страны. Так, инвестиции оказывают прямой эффект на укрепление социальных секторов страны, а программы, реализуемые ТНК в рамках корпоративной социальной ответственности (КСО), имеют дополнительное воздействие на социально-экономическое развитие страны.

Инвестиции составляют существенную долю от ВВП Вьетнама. Средняя доля инвестиций от ВВП Вьетнама в рассматриваемый период составила порядка 43,9\%. При этом вклад государственных инвестиций в формирование ВВП страны был наибольшим (среднее значение - 17,2\%). В период кризиса сохранению положительной динамики 
Таблица 5

Содействие многосторонних доноров развитию инфраструктуры за период 2006 - 2009 гг.

\begin{tabular}{|c|c|c|c|c|c|c|c|c|c|c|c|c|c|}
\hline & \multicolumn{3}{|c|}{2006} & \multicolumn{3}{|c|}{2007} & \multicolumn{3}{|c|}{2008} & \multicolumn{3}{|c|}{2009} & \multirow[b]{2}{*}{ Bcero } \\
\hline & $\begin{array}{l}\text { Управ- } \\
\text { ление } \\
\text { сектором } \\
\text { сельского } \\
\text { хозяй- } \\
\text { ства } \\
\end{array}$ & $\begin{array}{l}\text { Развитие } \\
\text { городской } \\
\text { и сельской } \\
\text { инфра- } \\
\text { структуры }\end{array}$ & $\begin{array}{l}\text { Тран- } \\
\text { спорт }\end{array}$ & $\begin{array}{l}\text { Управ- } \\
\text { ление } \\
\text { сектором } \\
\text { сельского } \\
\text { хозяйства }\end{array}$ & $\begin{array}{l}\text { Развитие } \\
\text { городской } \\
\text { и сельской } \\
\text { инфра- } \\
\text { структуры }\end{array}$ & $\begin{array}{l}\text { Tран- } \\
\text { спорт }\end{array}$ & $\begin{array}{l}\text { Управ- } \\
\text { ление } \\
\text { сектором } \\
\text { сельского } \\
\text { хозяй- } \\
\text { ства } \\
\end{array}$ & $\begin{array}{l}\text { Развитие } \\
\text { городской } \\
\text { и сельской } \\
\text { инфра- } \\
\text { структуры }\end{array}$ & $\begin{array}{l}\text { Тран- } \\
\text { спорт }\end{array}$ & $\begin{array}{l}\text { Управ- } \\
\text { ление } \\
\text { сектором } \\
\text { сельского } \\
\text { хозяй- } \\
\text { ства } \\
\end{array}$ & $\begin{array}{l}\text { Развитие } \\
\text { городской } \\
\text { и сельской } \\
\text { инфра-- } \\
\text { структуры }\end{array}$ & $\begin{array}{l}\text { Тран- } \\
\text { спорт }\end{array}$ & \\
\hline $\begin{array}{l}\text { Институты } \\
\text { ЕС }\end{array}$ & & 4,12 & & 0,56 & 3,20 & 0,23 & 0,52 & 3,58 & 0,07 & & 1,37 & 0,19 & 13,84 \\
\hline MAP & 35,33 & 3,59 & 53,37 & 76,49 & 6,48 & 33,89 & 51,05 & 6,13 & 63,04 & 60,51 & 23,51 & 59,21 & 472,60 \\
\hline Bcero & 35,33 & 7,70 & 53,37 & 77,06 & 9,69 & 34,17 & 51,57 & 9,71 & 63,12 & 60,51 & 24,88 & 59,39 & 486,45 \\
\hline
\end{tabular}

Источник: данные КСР ОЭСР, собственные расчеты автора.

роста доли инвестиций в ВВП стран способствовали государственные инвестиции, в то время как приток частных и иностранных капиталов в экономику Вьетнама снизился (средние доли от ВВП составили 15,9 и $10,8 \%$ соответственно).

Таблица 6

Доля потоков капитала от ВВП Вьетнама (2006-2010 гт.)

\begin{tabular}{|l|l|l|l|l|l|l|}
\hline & 2006 & 2007 & 2008 & 2009 & 2010 & $\begin{array}{l}\text { Cреднее } \\
\text { 3наче- } \\
\text { ние }\end{array}$ \\
\hline $\begin{array}{l}\text { Доля общего } \\
\text { объема } \\
\text { инвестиций от } \\
\text { ВВП (\%) }\end{array}$ & 41,6 & 46,5 & 41,6 & 42,7 & 47,2 & 43,9 \\
\hline $\begin{array}{l}\text { Доля } \\
\text { иностранных } \\
\text { инвестиций от } \\
\text { ВВП (\%) }\end{array}$ & 6,7 & 11,4 & 12,9 & 10,9 & 12,2 & 10,8 \\
\hline $\begin{array}{l}\text { Доля частных } \\
\text { инвестиций от } \\
\text { ВВП (\%) }\end{array}$ & 15,7 & 17,8 & 14,6 & 14,4 & 17,1 & 15,9 \\
\hline $\begin{array}{l}\text { Доля } \\
\text { государственных } \\
\text { инвестиций от } \\
\text { ВВП (\%) }\end{array}$ & 19,0 & 17,3 & 14,1 & 17,4 & 18,0 & 17,2 \\
\hline
\end{tabular}

Источник: Статистические даннье Правительства Вветнама, собственные расчеты автора.

Помимо государственных инвестиций преодолению кризисной и посткризисной волатильности частных и иностранных инвестиций способствовали потоки ОПР, в том числе помощи, предоставляемой многосторонними донорами, рассматриваемыми в данном исследовании. Так, при спаде общего уровня частных и иностранных инвестиций многосторонние доноры расширяли свои программы в целях содействия социальноэкономическому развитию страны (рис. 4).

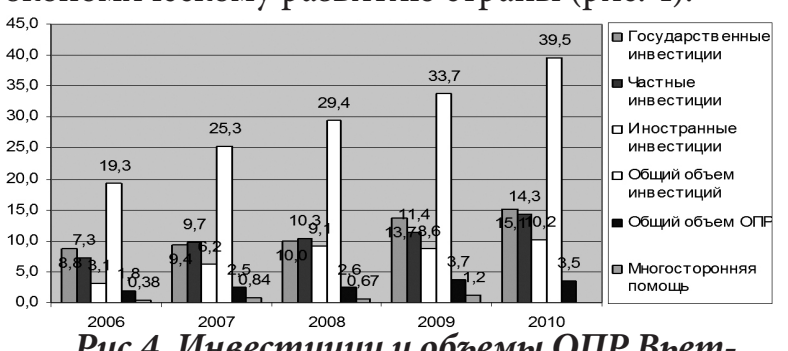

Рис.4. Инвестииии и объемь ОПР Вветнаму за период 2006 -2010 г2. (млрд долл. США)

Программы многосторонних доноров также способствовали преодолению негативных эффектов прихода в страну спекулятивного «короткого капитала», воздействие которого национальное правительство может слабо преодолеть в силу взаимосвязанности рынков различного вида капитала.
Торговля. Международная торговля также входит в число факторов интеграции развивающихся стран в мировую экономику. Интеграция Вьетнама в мировую экономику возможна не только за счет прямых эффектов торговли и инвестиций, но и за счет сближения страны с международными торговыми стандартами. Действия доноров по развитию торговли включают осуществление политических реформ, повышение торгового потенциала, а также решение торговых споров. В частности, исполнение критериев членства и вступление Вьетнама в ВТО при поддержке сообщества доноров стали несомненным фактором, способствовавшим снижению торговых барьеров.

Необходимо отметить, что Вьетнам стал третьим государством из числа стран, вошедших в «двадцатку» крупнейших получателей помощи для развития торговли, получив порядка 14,8 млрд долл. США за период с 2002 по 2009 г. ${ }^{24}$. Несмотря на то что доля помощи для развития торговли является незначительной относительно общего объема ОПР, за рассмотренный период доноры реализовали широкий круг программ в данной сфере. Наиболее эффективными стали программа ЕС по поддержке многосторонней торговой политики (EU's Multilateral Trade Policy Assistance Program, MUTRAP), а также проект США по укреплению торговли (United States'Support Trade Acceleration Project, STAR). Так, MUTRAP стала одной из крупнейших программ в рамках технической помощи по объему финансирования и масштабу распространения. Проект США был направлен на укрепление потенциала Вьетнама по исполнению двусторонних обязательств в сфере торговли, а также по вступлению страны в ВТО, для чего нужно было привести таможенное законодательство в соответствие с нормами BТО, а также повысить квалификацию госслужащих в сфере торговли. Проект STAR, также реализованный правительством США во Вьетнаме, способствовал росту экспорта Вьетнама в США более чем в четыре раза, при этом доля экспорта в США составила порядка половины от общего роста экспорта Вьетнама.

Вступление Вьетнама в ВТО способствовало количественному росту экспортно-импортных операций. Тем не менее страна продолжает оставаться чистым импортером, что свидетельствует о все еще низком уровне экспортного потенциала. 
Таблииа 7

Рост степени открытости экономики, доля от ВВП.

\begin{tabular}{|l|l|l|l|l|l|l|l|l|l|l|}
\hline & $\mathbf{1 9 9 4}$ & $\mathbf{1 9 9 5}$ & $\mathbf{1 9 9 6}$ & $\mathbf{1 9 9 7}$ & $\mathbf{1 9 9 8}$ & $\mathbf{1 9 9 9}$ & $\mathbf{2 0 0 0}$ & $\mathbf{2 0 0 1}$ & $\mathbf{2 0 0 2}$ & $\mathbf{2 0 0 3}$ \\
\hline Экспорт & 24,29 & 26,3 & 29,4 & 34,3 & 34,5 & 40,2 & 46,5 & 46,2 & 47,5 & 51 \\
\hline Импорт & 35,8 & 39,3 & 45,2 & 43,3 & 42,4 & 40,9 & 50,2 & 49,9 & 56,1 & 66,7 \\
\hline $\begin{array}{l}\text { 0бщий } \\
\text { объем } \\
\text { торговых } \\
\text { операций }\end{array}$ & 60,7 & 65,6 & 74,6 & 77,6 & 76,6 & 81,2 & 96,6 & 96,1 & 103,6 & 117,6 \\
\hline
\end{tabular}

Источник: Статистические данные ВТО, собственные расчеты автора ${ }^{25}$.

Помощь многосторонних доноров в развитии торговли во Вьетнаме была направлена на формирование политики и режимов регулирования торговых операций, создание торговой инфраструктуры, формирование производственного потенциала. При этом за рассмотренный период донорами было предоставлено в среднем $60 \%$ от обещанных средств для реализации программ в сфере развития торговли.

Таблица 8

Объемы помощи, предоставленной многосторонними донорами, в целях развития торговли Вьетнама (млн долл. СШАА) ${ }^{26}$

\begin{tabular}{|l|l|l|l|l|l|l|}
\hline & $\mathbf{2 0 0 6}$ & $\mathbf{2 0 0 7}$ & $\mathbf{2 0 0 8}$ & $\mathbf{2 0 0 9}$ & $\mathbf{2 0 1 0}$ & $\begin{array}{l}\text { (реднеe } \\
\text { 3наче- } \\
\text { ние }\end{array}$ \\
\hline $\begin{array}{l}\text { Обещанная } \\
\text { помощь }\end{array}$ & 1450,2 & 2141,9 & 2046,0 & 2608,1 & 2061,55 & 43,9 \\
\hline $\begin{array}{l}\text { Предос- } \\
\text { тавленная } \\
\text { помощь }\end{array}$ & 936,8 & 1277,0 & 1253,7 & 1466,6 & 1106,9 & 10,8 \\
\hline
\end{tabular}

К основным факторам успеха реализации многосторонними донорами программ в сфере содействия развитию торговли можно отнести:

- реализацию принципа национальной причастности (country ownership) при поддержке широкого круга заинтересованных лиц;

- устойчивые объемы финансирования;

- комбинирование государственных, частных источников финансирования;

- помощь, предоставленную многосторонними институтами.

Достижению положительных результатов, как правило, препятствовали такие факторы, как природные катастрофы, политические кризисы, рецессии.

Оценка воздействия многосторонней помощи на экономические показатели процессов развития. Можно попытаться оценить воздействие многосторонней помощи и обычной помощи доноров (ОПР), направленных на социальноэкономическое развитие страны, а также мер по интеграции экономики Вьетнама в мирохозяйственные отношения (на примере инвестиций, участвующих в формировании ВВП). Для этого придется построить модель, включающую перечисленные факторы, принимая за основу производственную функцию Кобба-Дугласа $\mathrm{Y}=\mathrm{f}(\mathrm{K}, \mathrm{L})$, где Y- объем выпускаемой продукции (ВВП), Кобъем капитала, L-число единиц труда.

Для построения модели в нашем случае производственная функция будет дополнена включением в число переменных внешней помощи (AID), которая влияет на объем выпускаемой продукции (ВВП). Таким образом, производственную функцию можно записать в виде $\mathrm{Y}=\mathrm{f}(\mathrm{K}, \mathrm{L}, \mathrm{AID})$ (1). Вводя допущение, что равенство (1) является линейной функцией (функцией с постоянной отдачей от масштаба), получим выражение, описывающее детерминанты роста ВВП:

$\psi=\alpha+\beta \lambda+\delta \kappa+\varphi \alpha(2)$, где параметры $\alpha, \beta, \delta$, $\varphi$ характеризуют степень роста отдельных переменных (K, $\Lambda, A)$.

B нашем случае на величину $L$, количество трудоспособного населения, влияют такие параметры, как уровень здравоохранения и образования, а на величину $\mathrm{K}$ - уровень капитализации национальной экономики. В силу того что уровень капитализации экономики в случае развивающейся страны измерить достаточно проблематично, для упрощения модели примем допущение о том, что на величину К влияет объем инвестиций, формирующих ВВП.

Данные для расчета представленной модели взяты из ресурсов КСР ОЭСР, Всемирного банка, а также из статистики правительства Вьетнама. ВВП на душу населения Вьетнама был измерен в постоянных ценах (в долларах США). Данные о предоставленной помощи многосторонними организациями и ОПР были взяты из базы КСР ОЭСР. Период выборки охватил временной период с 2000 по 2010 г.

Проведем эконометрический анализ данных, отражающих объем ВВП, уровень капитала (инвестиций в ВВП), объем многосторонней помощи, численность занятых в экономике за период с 2000 по 2010 гг. Для этого построим регрессию для уравнения:

$$
\mathrm{GGDP}=\beta 0+\beta 1 \mathrm{GPOP}+\beta 2(\mathrm{INV})+\beta 3(\mathrm{AID})+\mathrm{e}(3)
$$

где GGDP - темпы роста ВВП, GPOP - темпы роста населения, INV - инвестиции в экономику страны, AID - объемы помощи, е - возможные ошибки.

Регрессионный анализ поможет выявить взаимосвязь переменных и оценить влияние экзогенных переменных (GPOP, INV, AID) на эндогенную переменную (GGDP).

Для анализа построим регрессии для двух случаев, когда под переменной AID принимаются объемы многосторонней помощи и общие объемы ОПР, предоставленные стране в период с 2000 по 2010 г. Итак, сначала рассмотрим объемы многосторонней помощи для переменной AID и проанализируем значимость переменных полученной регрессии и ее адекватность. Адекватность регрессии можно оценить по F-статистике. В нашем случае ее вероятность (Prob (F-statistic)) равна нулю. Это означает, что гипотеза о равенстве всех коэффициентов нулю отвергается. Коэффициент детерминации (R-squared) в нашем случае равен 0,99 , значение приближено к единице. Это означает, что рассматриваемая нами модель хорошо приближает исходные данные к действительности. 
Теперь оценим значения полученных отдельных коэффициентов перед переменными GPOP, INV, AID. Примем уровень значимости, равный $5 \%$, что означает вероятность ошибки, равную $5 \%$. T-statistics всех коэффициентов $(\beta 0, \beta 1, \beta 2, \beta 3)$ больше по модулю значения процентной точки распределения Стьюдента $t \alpha(n) 1,83$, для которой количество чисел степеней свободы равно 9, а уровень процентной точки равен 5. а их вероятность меньше 0,05. Следовательно, все коэффициенты с вероятностью 5\% являются значимыми, то есть больше нуля.

С содержательной точки зрения значение коэффициентов означает, что:

- при росте параметра INV на 1 ед. значение GGDP увеличивается на 2,39;

- при росте параметра AID (Multilateral aid) на 1 ед. значение GGDРувеличивается на 1,06;

- при росте параметра GPOP на 1 ед. значение GGDP увеличивается на 1,3.

Таблица 9

Результаты оценки регрессионной модели при учете многосторонней ОПР.

\begin{tabular}{|c|c|c|c|c|}
\hline \multicolumn{3}{|c|}{ Dependent Variable: GDP } & & \\
\hline \multicolumn{5}{|c|}{ Method: LeastSquares } \\
\hline \multicolumn{5}{|c|}{ Includedobservations: 11} \\
\hline Variable & Coefficient & Std. Error & t-Statistic & Prob. \\
\hline $\mathrm{INV}^{*}$ & 2.397485 & 0.585826 & 1.892485 & 0.0046 \\
\hline MULTILATERAL_AID* & 1.064442 & 7.053187 & -4.888172 & 0.0039 \\
\hline GPOP & 1.300309 & 0.001061 & -3.291503 & 0.0091 \\
\hline$c$ & 16.45390 & 39.03130 & 2.421557 & 0.6860 \\
\hline R-squared & 0.990140 & \multicolumn{2}{|c|}{ Meandependentvar } & 46.07273 \\
\hline Adjusted R-squared & 0.985914 & \multicolumn{2}{|c|}{ S.D. dependentvar } & 22.85761 \\
\hline S.E. ofregression & 2.712860 & \multicolumn{2}{|c|}{ Akaikeinfocriterion } & 5.109172 \\
\hline Sumsquaredresid & 51.51727 & \multicolumn{2}{|c|}{ Schwarzcriterion } & 5.253861 \\
\hline Loglikelihood & -24.10044 & \multicolumn{2}{|c|}{ Hannan-Quinncriter. } & 5.017965 \\
\hline F-statistic & 234.3053 & \multicolumn{2}{|c|}{ Durbin-Watsonstat } & 2.205875 \\
\hline Prob(F-statistic) & 0.000000 & & & \\
\hline
\end{tabular}

Источник: Собственные расчеты автора, где INV ${ }^{*}=I N V /$ GDP, MULTILATERAL_AID ${ }^{*}=$ MULTILATERAL_AID/GDP.

Далее рассмотрим случай регрессии, когда показатель ODA принимает значение объема общей ОПР. Проделав ту же самую последовательность операций, получим следующие показатели. Как и предыдущем случае, регрессия является адекватной, поскольку F-статистика, вероятность F-статистики (Prob (F-statistic)) равна нулю. Значение $R$-squared также приближено к $1(0,99)$. Полученные отдельные коэффициенты $(\beta 0, \beta 1, \beta 2, \beta 3)$ перед переменными GPOP, INV, AID являются значимыми, поскольку их значения при уровне значимости равном 5\% по модулю больше значения процентной точки распределения Стьюдента ta (n) 1,83 .

Рассмотрим содержательное значение этих коэффициентов. Так при росте параметра INV*на 1 ед. значение GGDP увеличивается на 1,68. При росте параметра AID (General ODA) на 1 ед. значение GGDP увеличивается на 1,34 . При росте параметра GPOP на 1 ед. значение GGDP увеличивается на 1,0004 .

Значения регрессионной модели при общей ОПР.

\begin{tabular}{|c|c|c|c|c|}
\hline \multicolumn{3}{|c|}{ Dependent Variable: GDP } & & \\
\hline \multicolumn{3}{|c|}{ Method: Least Squares } & & \\
\hline \multicolumn{3}{|c|}{ Includedobservations: 11} & & \\
\hline Variable & Coefficient & Std. Error & t-Statistic & 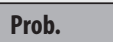 \\
\hline $\mathrm{INV}^{*}$ & 1.685392 & 0.354105 & 4.759585 & 0.0021 \\
\hline GENERAL_ODA* & 1.348071 & 2.667545 & 1.955113 & 0.0497 \\
\hline GPOP & 1.000480 & 0.000789 & 1.967823 & 0.0025 \\
\hline$C$ & 15.17794 & 30.35305 & -0.500047 & 0.6324 \\
\hline R-squared & 0.991044 & \multicolumn{2}{|c|}{ Meandependentvar } & 46.07273 \\
\hline Adjusted R-squared & 0.987206 & \multicolumn{2}{|c|}{ S.D. dependentvar } & 22.85761 \\
\hline S.E. ofregression & 2.585468 & \multicolumn{2}{|c|}{ Akaikeinfocriterion } & 5.012978 \\
\hline Sumsquaredresid & 46.79251 & \multicolumn{2}{|c|}{ Schwarzcriterion } & 5.157667 \\
\hline Loglikelihood & -23.57138 & \multicolumn{2}{|c|}{ Hannan-Quinncriter. } & 4.921771 \\
\hline F-statistic & 258.1993 & \multicolumn{2}{|c|}{ Durbin-Watsonstat } & 2.719737 \\
\hline $\operatorname{Prob}(F-$-statistic) & 0.000000 & & & \\
\hline
\end{tabular}

Источник: собственные расчеты автора, где $I N V^{*}=I N V /$ GDP, GENERAL_ODA* = GENERAL_ODA /GDP.

Построенная регрессия показала, что оцененные коэффициенты экзогенных переменных являются статистически значимыми. Оцененный коэффициент детерминации $(R$-squared) близка по значению к 1 , что указывает на то, что построенная модель приближает данные близко к действительности. При этом модель выявила, что инвестиции, участвующие в формировании ВВП Вьетнама, имеют большее воздействие на социально-экономическое развитие страны, чем ОПР, предоставленная донорамИ, в том числе многосторонними донорами (коэффициенты экзогенной переменной INV* превышают значение коэффициентов экзогенной переменной MULTILATERAL AID ${ }^{*}$ и GENERAL ODA ${ }^{*}$ ).

Полученные данные сопоставимы с данными, которые были получены в результате предыдущих исследований о влиянии помощи на ВВП, проведенных зарубежными учеными. Тем не менее результаты некоторых исследований показывают отрицательную взаимосвязь между ВВП на душу населения и объемами иностранной помощи. Это можно объяснить тем, что данные могли быть получены из различных источников, и тем, что данные являются междисциплинарными по своему содержанию.

Более того, причиной эффекта негативного влияния ОПР на ВВП могли также стать такие факторы, как вооруженные конфликты, демографические кризисы, региональные особенности. Иностранная помощь может иметь различное влияние на экономический рост одних и тех же регионов в разные периоды времени. ОПР также имеет различное влияние на различные группы стран. Так, в большинстве случаев стран Африки ОПР способствует экономическому росту, в то время как негативное воздействие на экономический рост ОПР имеет для стран с уровнем дохода ниже среднего, что объясняется такими факторами, как коррупщия.

Заключение. В целом количественный и качественный анализ демонстрирует, что в политическом диалоге между правительством Вьетнама и многосторонними донорами не ставится акцент на развитии социальных вопросов, таких, как здравоохране- 
ние или образование. Внимание многосторонних доноров сконцентрировано на решении вопросов развития национальной экономики страны, а также ее интеграции в процессы мировой экономики через торговые операции и инвестиции.

На примере отдельно взятой страны можно четко проследить усиление влияния инвестиций (в том числе ПИИ) на рост ВВП, следовательно, и на социально-экономическое развитие страны в целом. Несмотря на то что в построенную в исследовании модель влияния помощи на ВВП не были включены помощь в укреплении экспортного потенциала, а также внедрение инновационных механизмов содействия развитию. Тем не менее было доказано, что воздействие инвестиций на социально-экономическое развитие Вьетнама является весьма значительным. Проведенный в статье анализ показал, что многосторонние институты развития делают упор на меры, способствующие более интенсивной интеграции стран-партнеров в меняющиеся мирохозяйственные связи.

На примере содействия развитию Вьетнама выявлено, что природа и парадигма содействия международному развитию меняется. Темпы роста и объемы ПИИ превышают темпы роста и объемы помощи. Степень независимости от внешних искусственных источников роста стран-получателей помощи увеличивается при соответствующей оценке потребностей местного населения и стран. Для достижения этой цели необходимо рассматривать взаимозависимость и последовательность различных направлений государственной политики. Страны должны использовать возможности потоков международных инвестиций и торговли для интеграции в мировую экономику и расширения внутренних рынков стран-получателей помощи.

Y.K. Zaytsev. Assessmente of the Impact of Multilateral Mechanisms of Assistance in Socio-Econovic Development of Viet Nam.

Summary: The article provides analysis of multilateral donors' measures directed at assisting Viet Nam to develop its social and economic sector. The author examines programs of multilateral donors, implemented in the main sectors of international development assistance and makes assessment of how these programs effect the indicators of social and economic development. In conclusion the author highlights the tendency of shifting multilateral donors' measures from traditional development programs to integration of partner countries into the processes of world economy, revealed on the basis of econometrics model.

\section{Ключевые слова}

Вьетнам, содействие международному развитию (СМР), социально-экономическое развитие, многосторонние банки развития, официальная помощь развитию (ОПР), инновационные механизмы финансирования развития, частно-государственное партнерство (ЧГП), прямые иностранные инвестиции (ПИИ).

\section{Keywords}

Viet Nam, international development assistance, socialeconomic development, multilateral development banks, official development assistance (ODA), development financing innovation mechanisms, privatepublic partnership (PPP), foreign direct investments (FDI).

\section{Примечания}

1. All ODA figures in this section are based on data provided to the evaluation by MPI.

2. Both percentages increased temporarily in 2009 due to emergency support from the development banks for GoV's stimulus packages

3. "Review of the Progress on the Realization of ODA Strategic Framework for 2006 - 2010 period and ODA vision beyond 2010 ", Presentation by Dr. Ho Quang Minh, Director General, FERD, MPI, June 2010.

4. Paris Declaration/Hanoi Core Statement Phase 2 Evaluation

5. The Education System in Vietnam, by Christopher Runckel, Business in Viet Nam. URL: http://www.business-in-asia.com/vietnam/education system_in_vietnam.html

6. The Five Year Socio-Economic Development Plan 2006-2010, the Socialist Republic of Vietnam, the World Bank official web site, July 2005. URL: http://siteresources.worldbank.org/INTPRS1/Resources/Vietnam PRSP\%28July-2006\%29.pdf

7. Resolution on Complex and Fundamental Reform of the Higher Education System in Viet Nam for the period of 2006-2020, the official web site of the Ministry for Education and Training of Vietnam. URL: http://en.moet.gov.vn/?page=8.9\&view=4562

8. Viet Nam education expenditures. URL: http://www.indexmundi.com/facts/vietnam/education-expenditure

9. Viet Nam: Development Effectiveness. Country brief. URL: http://www.adb.org/Documents/Brochures/Devt-Effectiveness-Country-Briefs/ Viet-Nam.pdf

10. Samuel S. Lieberman, Adam Wagstaffh. Health Financing and Delivery in Viet Nam. The World Bank, 2009.

11. Доклад ВОЗ о состоянии здоровья в мире. URL:http://www.who.int/features/qa/74/ru/index.html

12. Viet Nam - National Expenditure on Health, the official web site of World Health Organization. URL: http://apps.who.int/nha/database/ StandardReport.aspx?ID=REP WEB MINI TEMPLATE WEB VERSION\&COUNTRYKEY $=84518$

13. The official web site of the World Health Organisation, Viet Nam. URL:http://www.who.int/countries/vnm/en/

14. General Statistics office of Viet Nam. URL: http://www.gso.gov.vn/default_en.aspx?tabid=468\&idmid=3\&ltemID=9899

15. Vietnam," Fighting a Rising Tide:The Response to AIDS in East Asia; (eds. Tadashi Yamamoto and Satokoltoh). Tokyo: JapanCenter for International Exchange, 2006, pp. 266-284. URL: http://www.jcie.org/researchpdfs/RisingTide/vietnam.pdf

16. External aid for health in Viet Nam: additional or fungible? Rebecca Dodd, Chris D James and Nguyen Thi Kim Phuong.World Health Organization, 2010.

17. Joint Annual Health Review, 2008. Health Financing in Viet Nam. Health Partnership Group, Ministry of Health Viet Nam.

18. Review of Public Spending to Agriculture, A Joint DFID/ World Bank Study. January, 2007. URL: http://www1.worldbank.org/publicsector/ pe/pfma07/OPMReview.pdf

19. FAO's main in-country programmes: Viet Nam, the official web site of Food and Agriculture Organization. ORL: http://www.fao.org/ countries/55528/en/vnm/

20. Development Effectiveness Country Brief. Viet Nam. Asian Development Bank, 2009.

21. Law on Foreign Investments in Vietnam. Adopted by the National Assembly of The Socialist Rebublic of Vietnam on 12 November 1996. URL: http://www.vietnamlaws.com/freelaws/LFIna12Nov96\%28aa9Jun00\%29\%5BI1\%5D.pdf

22. OECD Investment Policy Reviews: Viet Nam 2009.

23. OECD Investment Policy Reviews: Viet Nam 2009

24. Aid for Trade at a Glance: Showing Results. OECD, WTO, 2011.

25. Aid for Trade at a Glance 2011: Showing Results, the official web site of World Trade Organisation. URL: http://www.wto.org/english/res_e/ publications e/aid4trade11 e.htm

26. Aid for Trade at a Glance 2011: Showing Results. The official web site of WTO.URL: http://www.wto.org/english/res_e/booksp_e/a4t11_23_ stat_notes_e.pdf 